\title{
Entrepreneurship Education in Public Universities in Ekiti State, Nigeria
}

\author{
Aina M. Adebayo* \\ Department of Vocational and Technical Education, Faculty of Education, Ekiti State University, Ado Ekiti, Nigeria
}

Corresponding author: Aina M. Adebayo,E-mail: ainaadebayo2013@gmail.com

\begin{tabular}{l} 
ARTICLE INFO \\
\hline Article history \\
Received: June 23, 2018 \\
Accepted: October 24, 2018 \\
Published: October 31, 2018 \\
Volume: $6 \quad$ Issue: 4 \\
\hline
\end{tabular}

Conflicts of interest: None

Funding: None

\begin{abstract}
The inclusion of entrepreneurship education to university curriculum is to make the content more functional. However, it seems that entrepreneurship education has not been achieving its objectives in Nigeria. The main purpose of this study was to compare entrepreneurship education in two public universities in Ekiti State. The survey research design was adopted. The sample of the study consisted of 101 lecturers/trade experts from these universities. Two questionnaires were used to collect data. The instruments were validated by two lecturers from Ekiti State University (EKSU) and the Federal University, Oye Ekiti (FUOYE). The reliability test yielded a coefficient of 0.73 . The findings showed that lecture method was mostly used in the two institutions, among others. Based on the findings of this study, it was recommended that adequate instructional materials should be provided. Also, the use of field trip is recommended to enable the students to receive first-hand information about these entrepreneurship trades from the appropriate companies/sites/industries, among others.
\end{abstract}

Key words: Appraisal, Entrepreneurship, Entrepreneurship Education, Public Universities

\section{INTRODUCTION}

The economies of most developing nations such as Nigeria and Gambia are moving towards a direction where only individuals with self-sustaining and saleable skills can really survive. This is evident by the rate at which unemployment among Nigerian graduates are increasing yearly. Thus, National Universities Commission (NUC) (2011) reported that the Federal Government directed that entrepreneurship studies should be introduced into the curriculum of university education in Nigeria. The philosophy of entrepreneurship education is to produce graduates with some value addition over and above their field of study for the purpose of self-reliance. In line with this policy thrust, NUC was directed to design the curricula and course specifications for entrepreneurship education for the undergraduate programmes regardless of their disciplines.

European Commission (2008) defined entrepreneurship as an individual's ability to turn ideas to actions and includes creativity, innovation and risk taking as well as the ability to plan and manage projects in order to achieve objectives. Ekpenyong (2010) states the objectives of entrepreneurship include establishment of entrepreneurship mindset; production of responsible and enterprising individuals who will become entrepreneurs, and/or entrepreneurial thinkers who could contribute to the economic development and poverty alleviation in Nigeria; recognition of opportunities; and generation of ideas and compilation of resources to pursue opportunities while recognizing the risks. Similarly,
Nwangwu (2007) defined entrepreneurship as a process of bringing together the factors of production, which include land, labour and capital so as to produce a product or service for public consumption. Entrepreneurship education therefore can be defined as that type of education which deals with the inculcation into the students, the ability to study one's environment and make use of available opportunities into some economic gains. Also, Afolabi, Yusuf, Ogunjobi and Idowu (2014) affirm that entrepreneurship education is a process that equips individuals with entrepreneurial skills, knowledge and right attitude to work and sharpen their talents, natural endowments and competencies so as to make them self-reliant, self-employed and employers of labour.

Generally, the goal of entrepreneurship education is to reduce unemployment among graduates through acquisition of appropriate skills that will enable students to embark on economic venture on their own after graduation. NUC (2011) identified the broad objectives of entrepreneurship education to include:

- To redirect education/training for relevance and quality by developing in the undergraduate/graduate an entrepreneurial mindset (spirit) and equipping him with the skills necessary to start and run a business successfully; and

- To introduce students to the key requirements for starting an enterprise.

Since the introduction of entrepreneurship education in higher institutions commenced across the nation, a survey of 
some universities' handbooks on entrepreneurship education programme reveal that there are differences in the course contents being taught in these institutions. Each university seems to develop its programme based on how it conceptualizes it.

In view of the fact that knowledge acquisition is partly dependent on the pedagogy of the teacher or lecturer, it is therefore important to identify appropriate methods of entrepreneurship education. Ajayi (2004) lists some of the teaching methods that include lecture, demonstration, group discussion, and field trip, among others. A study conducted by Onagite and Aina (2017) revealed that teaching methods used in entrepreneurship were basically theoretical which needs to be improved with practical knowledge and skills for students' preparation for future career in the world of work. Also, the findings of Co and Mitchell (2006) showed that entrepreneurship education focuses on traditional classroom delivery such as lectures. An observation of the present methods used in entrepreneurship education in these institutions seems to reveal that project method, lecture method, demonstration and question and answer method, assignment, and discussion are mostly used. Most of these methods are teacher-centered, which did not allow the students to actively participate in the learning process. This seems to account for the failure of entrepreneurship education to yield desired results. Byun, Sung, Park and Choi (2018) noted that entrepreneurship graduate schools should provide methods and contents to discover opportunities and challenge risks in an uncertain environment. They observed that it is desirable to invite qualified entrepreneurs and lecturers to improve the content and quality of entrepreneurial subjects with high importance. Thus, there is need for an activity-based method which is student-centered such as experiential teaching method.

Experiential learning is the process of learning through experience. It is more specifically defined as learning through reflection on doing. Experiential learning is concerned with more concrete issues related to the learner and the learning context, (Kolb, Robin and Mclntyre, 1974). Experiential learning method would be a better approach to entrepreneurship education. In support of this, Ajayi and Ayodele (2002) reported that recipients of indigenous education were exposed to a wide range of vocations and occupations which include farming, fishing, boat-making, mat-making, pottery-making, soap-making, animal-husbandry, weaving, hair plaiting, bead working, carpentry and dressmaking. Thus, there was no room for unemployment in the African traditional setting as traditional education emphasised self-employment.

In contemporary era, experiential learning has been formalized by Kurt Lewin and the T-Group Movement in the 1940s and other great thinkers in the field of philosophy and educational psychology like Paulo Freire, John Dewy, Jerome Bruner, Kurt Hahn, and Carl Roggers, among others.

Entrepreneurship has been identified as a remedy against unemployment and stagnant economic growth, hence, the need to ascertain the availability of resources needed for effective and practical-oriented entrepreneurship education is germane. Egbe in Ikegwuani (2015) stated that the rates of learning through five senses give an immediate picture of the vital role of audio visual materials in teaching/learning process. It is therefore practically impossible for a learner to be successful in any skill acquisition programme that does not involve the effective use and manipulation of learning materials. This view is in consonance with Umar $(20 \mathrm{xx})$ in Harnau (2014) when he pointed out that capacity building aimed at developing the human resources being a key element in quality and quantity in manpower development for specific tasks. In view of this, it is expected that the required instructional resources, as listed in the 2011 NUC benchmark will be provided.

Thus, Afolabi et al. (2014) and Ikegwuani (2015) reported that provision of modern working tools, maintenance of aesthetically pleasing working environment, modern audio-visual materials, equipment, relia, laboratory, power supply and gadgets must be adequately provided at the Centre for Entrepreneurship Education (CEE) to enable the teacher and learners add more knowledge and compare ideas. Thus, NUC (2011) benchmark for minimum standards in entrepreneurship provided a list of 34 trades/skills and instructional resources needed for effective teaching of these trades. This is to enable the institutions to produce more enterprising, qualified and skill-oriented graduates who would be able to contribute significantly to the growth of the nation's economy by increasing self employment. Based on the high premium placed on the use of instructional resources in entrepreneurship education, it is therefore important to identify the available instructional resources at Centre for Entrepreneurship Education (CEE) that will guarantee effective teaching in these institutions. In his contribution, Nwokike (2015) observed that government needs to provide money for funding the universities by providing facilities for teaching the students This will enable Nigeria university graduates possess employable skills through involvement in relevant practical activities in entrepreneurship education. However, Ayodele (2008) listed some of the obstacles/challenges to effective entrepreneurship development in Nigeria to include: Inadequate capital, irrelevant education, low level of infrastructural development, overt problems of procuring materials, among others.

The rate at which unemployment is increasing on yearly basis is becoming a source of concern to parents, governments and lecturers in spite of the introduction of entrepreneurship education in the nation's tertiary institutions. There seems to be hindrances against effective entrepreneurship education which has not allowed the course to achieve its set objectives. These include unconducive learning environment, method of teaching, inadequate instructional materials, among others (Ekpenyong, 2010). It is against this background that this study appraised entrepreneurship education in Ekiti State University, Ado-Ekiti (EKSU) and the Federal University, Oye-Ekiti (FUOYE).

\section{Purpose of the Study}

The main purpose of this study was to compare the entrepreneurship education in public universities in Ekiti State. Specifically, the study determined:

1. pedagogical approaches used for entrepreneurship education; 
2. the extent of availability of instructional resources/facilities for entrepreneurship education; and

3. challenges of entrepreneurship education in public universities in Ekiti State.

\section{Research Questions}

The following research questions were raised and answered to guide the study:

1. What are the pedagogical approaches used in entrepreneurship education in public universities in Ekiti State?

2. What are the instructional resources available for entrepreneurship education in public universities in Ekiti State?

3. What are the challenges of entrepreneurship education in these universities?

\section{METHODS}

The descriptive research design of the survey type was used for this study. This design sought to collect data on the opinions of the respondents with a view to comparing the teaching methods used in two public universities in Ekiti State.

\section{Sample}

The population of the study was made up of 121 entrepreneurship education lecturers and adjunct trade experts in the two institutions, consisted of 86 and 35 from EKSU and FUOYE respectively. Entrepreneurship education lecturers and trade experts $(n=101)$ were randomly selected as the sample for this study. From EKSU and FUOYE respectively 76 and 25 respondents were randomly selected. The remaining 20 members (that is, 10 from each of the institutions) were used to carry out the reliability test.

\section{Instrument}

To test the reliability of 'Entrepreneurship Education in Public Universities' (EEPU) questionnaire, split half method was used. The scores collected were subjected to Pearson Product Moment Correlation formula which yielded a coefficient of 0.73 .

Table 1 indicates the level of availability of the teaching resources in these institutions since the required numbers were not expressly stated in the NUC (2011) Benchmark.
In arriving at the decision in Table 1, the researcher considered the quantity available vis-à-vis the population of students in groups. To ascertain the validity of the instrument, the drafts were submitted to two lecturers, one from each of the entrepreneurship centres of the two institutions. Their comments and corrections made by these experts were incorporated into the final copy of the instruments.

\section{Data Analysis}

Data were analysed using descriptive statistics, and more specifically, mean values. Items with means of 2.50 or above were regarded as 'Agree' while items with values below 2.50 were considered 'Disagree'.

\section{RESULTS}

\section{Pedagogical Approaches Used in Entrepreneurship Education}

Research Question 1: What are the pedagogical approaches used in entrepreneurship education in public universities in Ekiti State?

The analysis of result in Table 2 reveals that out of the twelve (12) pedagogical approaches listed respondents from EKSU agreed on adequate use of teaching methods on items $1,4,6,7,8$, and 11 while respondents from FUOYE are of the opinion that methods on items $1,3,4,5,7,10$, and 11 are mostly used in tertiary entrepreneurship education.

The analysis revealed that the two institutions are commonly using lecture, demonstration and assignment methods (i.e., items 1, 4 and 7) as the mean scores of the items are above 2.50 cut off point in the two institutions. Other teaching methods listed in items 2,9 and 12 are the least used methods with cut off point of less than 2.50.

\section{Instructional Resources Available for Teaching Entrepreneurship}

Research Question 2: What are the instructional resources available for teaching entrepreneurship in public universities in Ekiti State?

In order to answer the research question, the NUC Benchmark for minimum academic standards for undergraduate programmes in Nigerian universities was used to ascertain the required instructional resources in each of the trades

Table 1. Self-developed rating scale on measure of availability of instructional resources needed for entrepreneurship education

\begin{tabular}{|c|c|c|c|c|}
\hline & Quantity & Quantity available & Points & Decision \\
\hline i. & $\begin{array}{l}\text { Litres of liquid or units of tools: } \\
* \text { Absent } \\
* \text { Sparsely available } \\
* \text { Adequately available } \\
* \text { Highly available }\end{array}$ & $\begin{array}{c}0 \\
1-10 \\
11-20 \\
21+\end{array}$ & $\begin{array}{l}1 \\
2 \\
3 \\
4\end{array}$ & $\begin{array}{l}\text { Not available } \\
\text { Inadequate } \\
\text { Adequate } \\
\text { Very adequate }\end{array}$ \\
\hline ii. & $\begin{array}{l}\text { Land/Laboratories: } \\
\text { Equipment/Laboratory } \\
\text { Equipment/Laboratory }\end{array}$ & $\begin{array}{c}1 \\
2+\end{array}$ & $\begin{array}{l}3 \\
4\end{array}$ & $\begin{array}{l}\text { Adequate } \\
\text { Very adequate }\end{array}$ \\
\hline
\end{tabular}


Table 2. Mean scores of pedagogical approaches used in entrepreneurship education in the public universities in ekiti state

\begin{tabular}{|c|c|c|c|c|c|}
\hline \multirow[t]{2}{*}{$\mathbf{S} / \mathbf{N}$} & \multirow[t]{2}{*}{ Teaching Methods } & \multicolumn{2}{|c|}{ EKSU } & \multicolumn{2}{|c|}{ FUOYE } \\
\hline & & Mean & Decision & Mean & Decision \\
\hline 1. & Lecture method is used to teach the principles in entrepreneurship education. & 3.11 & Agree & 3.13 & Agree \\
\hline 2. & Question and answer method of teaching entrepreneurship is also used. & 1.76 & Disagree & 1.92 & Disagree \\
\hline 3. & Use of field trip/excursion is being used to teach entrepreneurship education. & 1.69 & Disagree & 2.61 & Agree \\
\hline 4. & Demonstration method was used to teach students. & 2.63 & Agree & 2.88 & Agree \\
\hline 5. & Individual and group project method is used for teaching entrepreneurship. & 1.70 & Disagree & 2.79 & Agree \\
\hline 6. & Textbook method is used for entrepreneurship education. & 3.01 & Agree & 1.85 & Disagree \\
\hline 7. & $\begin{array}{l}\text { Assignment method is used to teach my students in entrepreneurship } \\
\text { education. }\end{array}$ & 2.57 & Agree & 2.73 & Agree \\
\hline 8. & Debate is used as a method for teaching entrepreneurship. & 2.85 & Agree & 1.53 & Disagree \\
\hline 9. & $\begin{array}{l}\text { Use of problem solving method in entrepreneurship education is more } \\
\text { relevant. }\end{array}$ & 1.68 & Disagree & 2.08 & Disagree \\
\hline 10. & $\begin{array}{l}\text { Brainstorming enhances students' skill acquisition in entrepreneurship } \\
\text { education. }\end{array}$ & 2.04 & Disagree & 2.86 & Agree \\
\hline 11. & Dramatization is used to teach entrepreneurship. & 3.09 & Agree & 2.58 & Agree \\
\hline 12. & $\begin{array}{l}\text { Recitation method can be effectively used to teach entrepreneurship } \\
\text { education. }\end{array}$ & 1.01 & Disagree & 1.92 & Disagree \\
\hline
\end{tabular}

specified. Also, the self-developed rating scale on availability in Table 1 was used as a guide to measure level of availability.

A careful study of the available entrepreneurship trades in the two universities revealed that out of the 34 trades in the NUC Benchmark, only thirteen (13) trades are being taught in the two institutions. In view of the foregoing, the table below presents the analysis of the data collected on the available instructional resources in the trades:

Table 3 reveals that the instructional resources in items 13 and 14 are completely and adequately available in the two institutions as each of them had 3 points and above. This means that all the required items/materials for effective teaching and learning of soap/detergent/toothpaste (item 13) and cloth/textile (item 14) are adequately provided. Also, food processing (items 15) and building drawing (item 22) revealed that only Ekiti State University, Ado-Ekiti have instructional resources in food processing and building drawing while the two trades are not available at FUOYE. The data collected on items 16, $17,18,19,20,2123,24$ and 25 revealed that some instructional resources needed for these trades are very adequately available, some are adequately available while few are not adequately available in the two institutions.

\section{Challenges of Teaching Entrepreneurship}

Research Question 3: What are the problems/challenges of teaching entrepreneurship in your university?

Table 4 revealed that out of the ten (10) identified challenges, respondents from EKSU agreed that only items 31 and 33 are not challenges to effective entrepreneurship education while respondents from FUOYE agreed that items 27 , $29,33,34$, and 35 are not challenges to effective entrepreneurship education. The analysis revealed that the two institutions agreed that items 33 (lecturers' attitude to students) is not a challenge to effective entrepreneurship education.

\section{DISCUSSION}

The finding of the study revealed that most of the methods used to teach entrepreneurship education in EKSU are teacher-centred, while the finding from FUOYE revealed that field trip/excursion is used to teach their students, which is one of the viable student-centred teaching methods. This may enable FUOYE students to be well-equipped in entrepreneurship skill acquisition. The finding suggests that there was a preference for academic implication at EKSU and practical implication at FUOYE. This is in support of the findings of Mwatsika and Sakhulani (2016) that entrepreneurship education affects students' knowledge (academic implication), perception of having adequate skills and competencies (practical implication) to engage with entrepreneurship practical successfully. The finding is in contrary to the recommendation of NUC (2011) that methods of delivery should be mentoring and practical in business incubator/existing business. This can only be found in pedagogical approaches like field trip/excursion and demonstration.

Also, the study revealed that in Ekiti State University, Ado Ekiti, out of the 13 available trades only 3 trades, (soap/ detergent/toothpaste making, food processing and tailoring) adequately have all the needed materials for effective teaching and learning, while the remaining 10 trades are not adequately equipped in one or two of the instructional resources needed to learn the trades effectively. The findings on available resources in Federal University, Oye Ekiti revealed that soap/detergent/toothpaste and cloth dyeing are adequately equipped at FUOYE. Generally, it was also found out that there are no enough instructional resources to teach the available entrepreneurial trades in these universities. The finding is in support of Nwokike (2015) when she noted that facilities for teaching and learning are lacking in most universities in Nigeria. Also, in their own contribution, 
Table 3. Analysis of availability of instructional resources for entrepreneurship education in EKSU and FUOYE

\begin{tabular}{|c|c|c|c|c|c|c|c|}
\hline \multirow[t]{2}{*}{$\mathbf{S} / \mathbf{N}$} & \multirow{2}{*}{$\begin{array}{l}\text { Trades/instructional } \\
\text { resources }\end{array}$} & \multirow{2}{*}{$\begin{array}{l}\text { Qty } \\
\text { available }\end{array}$} & \multicolumn{2}{|l|}{ EKSU } & \multirow{2}{*}{$\begin{array}{l}\text { Qty } \\
\text { Available }\end{array}$} & \multicolumn{2}{|c|}{ FUOYE } \\
\hline & & & Points & decision & & Points & Decision \\
\hline \multirow[t]{5}{*}{13.} & $\begin{array}{l}\text { Soap/detergent/toothpaste } \\
\text { making: }\end{array}$ & & & & & & \\
\hline & i. Laboratory & 1 & 3 & Adequate & 1 & 3 & Adequate \\
\hline & ii. Chemicals & 15 & 3 & Adequate & 12 & 3 & Adequate \\
\hline & iii. Caustic soda & 15 & 3 & Adequate & 12 & 3 & Adequate \\
\hline & iv. PKO & 15 & 3 & Adequate & 12 & 3 & Adequate \\
\hline \multirow[t]{5}{*}{14.} & Cloth Dyeing/Textile: & & & & & & \\
\hline & i. Buckets & 17 & 3 & Adequate & 20 & 3 & Adequate \\
\hline & ii. Dye of different colours & 15 & 3 & Adequate & 12 & 3 & Adequate \\
\hline & iii. Chemicals & 15 & 3 & Adequate & 20 & 3 & Adequate \\
\hline & iv. Water & 25 & 4 & Very Adequate & 20 & 4 & Very Adequate \\
\hline \multirow[t]{3}{*}{15} & Food Processing: & & & & & & \\
\hline & i. Preservatives & 20 & 3 & Adequate & 0 & 1 & Not Available \\
\hline & $\begin{array}{l}\text { ii. Processing equipment } \\
\text { (Palm oil \& garri) }\end{array}$ & 2 & 4 & Very Adequate & 0 & 1 & Not Available \\
\hline \multirow[t]{5}{*}{16} & Photography: & & & & & & \\
\hline & i. Dark room (lab) & 1 & 3 & Adequate & 1 & 3 & Adequate \\
\hline & ii. Cameras & 7 & 2 & Inadequate & 5 & 2 & Inadequate \\
\hline & iii. Films & 7 & 2 & Inadequate & 5 & 2 & Inadequate \\
\hline & iv. Chemicals & 5 & 2 & Inadequate & 5 & 2 & Inadequate \\
\hline \multirow[t]{8}{*}{17.} & Poultry: & & & & & & \\
\hline & i. Site (Land) & 2 & 4 & Very Adequate & 2 & 4 & Very Adequate \\
\hline & ii. Incubator & 2 & 4 & Very Adequate & 1 & 3 & Adequate \\
\hline & iii. Water Supply & 25 & 4 & Very Adequate & 25 & 4 & Very Adequate \\
\hline & iv. Cages & 12 & 3 & Adequate & 8 & 2 & Inadequate \\
\hline & v. Egg Trays & 12 & 3 & Adequate & 8 & 2 & Inadequate \\
\hline & vi. Drinking trough & 6 & 2 & Inadequate & 4 & 2 & Inadequate \\
\hline & vii. Vaccines & 20 & 4 & Very Adequate & 20 & 4 & Very Adequate \\
\hline \multirow[t]{6}{*}{18.} & $\begin{array}{l}\text { Domestic electrical } \\
\text { Installation }\end{array}$ & & & & & & \\
\hline & i. Electrical workshop & 3 & 4 & Very Adequate & 3 & 3 & Adequate \\
\hline & ii. Soldering Iron & 8 & 2 & Inadequate & 7 & 2 & Inadequate \\
\hline & iii. Screw Drivers/Pliers & 8 & 2 & Inadequate & 8 & 2 & Inadequate \\
\hline & iv. Electrical toolbox & 2 & 2 & Inadequate & 2 & 2 & Inadequate \\
\hline & $\begin{array}{l}\text { v. Alternative Power } \\
\text { Supply }\end{array}$ & 1 & 2 & Inadequate & 1 & 2 & Inadequate \\
\hline \multirow[t]{6}{*}{19.} & $\begin{array}{l}\text { Welding, metal work and } \\
\text { Fabrication: }\end{array}$ & & & & & & \\
\hline & i. Workshop & 1 & 3 & Adequate & 1 & 3 & Adequate \\
\hline & ii. Tool kits & 2 & 2 & Inadequate & 1 & 2 & Inadequate \\
\hline & iii. Safety wear & 20 & 3 & Adequate & 12 & 3 & Adequate \\
\hline & iv. Welding machine & 1 & 2 & Inadequate & 1 & 2 & Inadequate \\
\hline & v. Soldering machine & 8 & 2 & Inadequate & 6 & 2 & Inadequate \\
\hline \multirow[t]{8}{*}{20.} & Wood work and carpentry & & & & & & \\
\hline & i. Workshop & 2 & 4 & Very Adequate & 1 & 3 & Adequate \\
\hline & ii. Safety wear & 18 & 3 & Adequate & 12 & 3 & Adequate \\
\hline & iii. Planks & 30 & 4 & Very Adequate & 21 & 4 & Very Adequate \\
\hline & iv. Chisels & 10 & 2 & Inadequate & 7 & 2 & Inadequate \\
\hline & v. Saw & 10 & 2 & Inadequate & 7 & 2 & Inadequate \\
\hline & vi. Hammer & 10 & 2 & Inadequate & 7 & 2 & Inadequate \\
\hline & $\begin{array}{l}\text { vii. Energy Source } \\
\text { (Generator) }\end{array}$ & 1 & 3 & Adequate & 1 & 3 & Adequate \\
\hline \multirow[t]{6}{*}{21.} & Radio and Television Repairs & & & & & & \\
\hline & i. Workshop & 3 & 4 & Very Adequate & 1 & 3 & Adequate \\
\hline & ii. T.V for practicals & 8 & 2 & Inadequate & 7 & 2 & Inadequate \\
\hline & iii. Robber gloves & 20 & 3 & Adequate & 18 & 3 & Adequate \\
\hline & iv. Technologists & 1 & 2 & Inadequate & 1 & 2 & Inadequate \\
\hline & v. Overall & 13 & 3 & Adequate & 8 & 2 & Inadequate \\
\hline
\end{tabular}


Table 3. (Continued)

\begin{tabular}{|c|c|c|c|c|c|c|c|}
\hline \multirow[t]{2}{*}{$\mathbf{S} / \mathbf{N}$} & \multirow{2}{*}{$\begin{array}{l}\text { Trades/instructional } \\
\text { resources }\end{array}$} & \multirow{2}{*}{$\begin{array}{l}\text { Qty } \\
\text { available }\end{array}$} & \multicolumn{2}{|l|}{ EKSU } & \multirow{2}{*}{$\begin{array}{l}\text { Qty } \\
\text { Available }\end{array}$} & \multicolumn{2}{|c|}{ FUOYE } \\
\hline & & & Points & decision & & Points & Decision \\
\hline \multirow[t]{5}{*}{22.} & Building Drawing: & & & & & & \\
\hline & i. Computer software & 4 & 2 & Inadequate & 0 & 1 & Not Available \\
\hline & ii. Drawing set & 12 & 3 & Adequate & 0 & 1 & Not Available \\
\hline & iii. Drawing board & 12 & 3 & Adequate & 0 & 1 & Not Available \\
\hline & iv. Drawing laboratory & 1 & 3 & Adequate & 0 & 1 & Not Available \\
\hline \multirow[t]{5}{*}{23.} & Farming (Crop) & & & & & & \\
\hline & i. Land & 1 & 3 & Adequate & 1 & 3 & Adequate \\
\hline & ii. Tractors & 1 & 3 & Adequate & 1 & 3 & Adequate \\
\hline & iii. Seedling & 12 & 3 & Adequate & 13 & 3 & Adequate \\
\hline & iv. Labour (unskilled) & 10 & 2 & Inadequate & 8 & 2 & Not Adequate \\
\hline \multirow[t]{6}{*}{24.} & Tailoring: & & & & & & \\
\hline & i. Workshop & 1 & 3 & Adequate & 1 & 3 & Adequate \\
\hline & ii. Sewing machines & 25 & 4 & Very Adequate & 20 & 3 & Adequate \\
\hline & iii. Weaving machines & 12 & 3 & Adequate & 8 & 2 & Inadequate \\
\hline & iv. Threads (per roll) & 30 & 4 & Very Adequate & 22 & 4 & Very Adequate \\
\hline & v. Needles (packs) & 14 & 3 & Adequate & 11 & 3 & Adequate \\
\hline \multirow[t]{5}{*}{25.} & Interior Decoration: & & & & & & \\
\hline & i. Cloths (yards) & 35 & 4 & Very Adequate & 25 & 4 & Very Adequate \\
\hline & ii. Iron rods (per length) & 18 & 3 & Adequate & 14 & 3 & Adequate \\
\hline & iii. Fittings & 10 & 2 & Inadequate & 10 & 2 & Inadequate \\
\hline & iv. Curtains (yards) & 30 & 4 & Very Adequate & 20 & 3 & Adequate \\
\hline
\end{tabular}

Source: Field work, 2017

Table 4. Mean scores of challenges of entrepreneurship education in public universities in Ekiti state

\begin{tabular}{|c|c|c|c|c|c|}
\hline \multirow[t]{2}{*}{$\mathbf{S} / \mathbf{N}$} & \multirow[t]{2}{*}{ Teaching methods } & \multicolumn{2}{|c|}{ EKSU } & \multicolumn{2}{|c|}{ FUOYE } \\
\hline & & Mean & Decision & Mean & Decision \\
\hline 26. & Inadequate number of hours for practical work & 2.63 & Agree & 2.74 & Agree \\
\hline 27. & Number of lecture hours per week are not enough & 2.90 & Agree & 1.82 & Disagree \\
\hline 28. & $\begin{array}{l}\text { Insufficient power supply to operate some } \\
\text { equipments }\end{array}$ & 3.02 & Agree & 2.59 & Agree \\
\hline 29. & Overcrowded lecture rooms & 2.95 & Agree & 1.73 & Disagree \\
\hline 30. & General shortage of teaching materials/equipment & 2.54 & Agree & 2.62 & Agree \\
\hline 31. & Students' poor attitude towards learning a vocation & 1.95 & Disagree & 2.82 & Agree \\
\hline 32. & $\begin{array}{l}\text { Poor funding for the purchase of needed instructional } \\
\text { resources }\end{array}$ & 3.25 & Agree & 2.75 & Agree \\
\hline 33. & $\begin{array}{l}\text { Lecturers' attitude to students in entrepreneurship } \\
\text { education lecture periods }\end{array}$ & 1.65 & Disagree & 1.52 & Disagree \\
\hline 34. & $\begin{array}{l}\text { Inadequate motivation/incentives for course } \\
\text { lecturers/trade experts }\end{array}$ & 2.86 & Agree & 1.93 & Disagree \\
\hline 35. & $\begin{array}{l}\text { Inadequate qualified trade experts to teach practical } \\
\text { entrepreneurship }\end{array}$ & 2.78 & Agree & 1.85 & Disagree \\
\hline
\end{tabular}

Source: Field work, 2017

Nnaji and Bagudu in Ikegwuani (2015) stated that most of the facilities required for training are lacking and sometimes inadequate in most of the institutions in Nigeria. These are in agreement with the findings of this study. In line with these findings, Harbau (2014) in a study conducted in Zaria concluded that there were needs for training and preparing teachers in entrepreneurship in order to enable them education the young generation.
In addition, the findings on the challenges of entrepreneurship education as considered by the researcher from existing literature revealed that all the respondents in the two institutions were unanimous in their opinion with all the items listed except item 22 which was to find out whether lecturers' attitude could be a problem in effective teaching and learning of entrepreneurship in their institutions. This implies that the respondents acknowledged that 
the nine items are problems/challenges of entrepreneurship education. This finding is in support of Okorie (2013), when he asserted that government under-funding affects the facilities to be provided for effective teaching, learning and research activities and type of teaching staff that can be engaged. Also, in agreement with this finding, Aina and Nwachuckwu in Ikegwuani (2015) stated that the trade subjects require laboratories and workshops where teaching and learning can take place and more classrooms/laboratories still need to be built so as to reduce overcrowding and shortage of facilities.

\section{CONCLUSION}

Based on the findings, it could be concluded that the 34 entrepreneurship trades recommended for teaching by the National Universities Commission are not fully implemented in these institutions. Also, the instructional resources needed for the practical demonstration in the available entrepreneurship trades are not totally available in most of the trades taught to enhance effective skill acquisition.

The following recommendations are made, according to the results of the current study.

1. Pedagogical approaches used for entrepreneurship education in these institutions should be extended to include field trip and demonstration method.

2. The management of the two institutions should endeavour to make adequate provision for the instructional resources needed for effective teaching and learning of entrepreneurship trades as stated in NUC Benchmark Minimum Academic Standards for the programme.

3. The management of these institutions should allocate more hours to practicals, reduce overcrowded lecture rooms by grouping the students, provide alternative power supply and employ more qualified trade experts to teach the practical aspect to ensure acquisition of entrepreneurial saleable skills.

\section{REFERENCES}

Afolabi F.O., Yusuf M.A., Ogunjobi O. P. \& Idowu E.K. (2014). Establishment and sustenance of viable entrepreneurship education centres in Nigerian tertiary institutions. prospects and challenges. Tie Journals of Arts and Educational Research, 2(1), 39-46. Retrieved from http://www.timejournals.org/tjaer

Ajayi, I. A. (2004) Social science methods. Ado Ekiti: Greenline Publishers.

Ajayi I.A. \& Ayodele J.B. (2002). History and Development of Education ( $1^{\text {st }}$ ed.). Petoa Educational Publishers, Ado Ekiti.

Ayodele, J. B. (2008). Obstacles to entrepreneurship education in Nigeria. In F. Omotoso, T.K.O. Aluko, O. I. Wale Awe and Gbenga Adaramola (eds.) Introduction to Entrepreneurship Development in Nigeria: University of Ado Ekiti Press, 117 - 124.

Ekpenyong, L. E. (2010). Business Education and Entrepreneurship in Nigeria: The missing link. A lead paper presented at the annual National Conference of Associa- tion of Business Educators of Nigeria (ABEN) at Federal College of Education, Osiele, Abeokuta.

European Commission (2010). Towards Greater Cooperation in Coherence in Entrepreneurship Education. Retrieved from http://www.upm.ro/proiecte/EEE/conferences/papers/s602 ydf.

European Commission (2008). Entrepreneurship in Higher Institution especially within non-business studies. Final report of the Expert Group. March. http://www.startent. en/component/k2/item/168.

Kolb, D.A, Robin, I.M. \& Mclntyre, J.M. (1974). Experiential Learning. THINK global school students yada and charis_communicate with aguarani_in_puerto-igauzu_Argentina.jpg Retrieved https://en.m.wikipedia. org/wiki/file: from Ikegwuani, V.U (2015). Availability of infrastructural facilities for Business Studies in Public and Private Secondary Schools in Onitsha North and South LGAs of Anambra State, Nigeria. Nigerian Journal of Business Education, 2(2), 129-138.

National Universities Commission (2011). Benchmark Minimum Academic Standards for Undergraduate Programmes in Nigerian Universities. GST Entrepreneurship, Abuja.

Nwangwu, I. O. (2007). Higher Education for self reliance: An imperative for the Nigerian Economy. In J. B. Babalola, G. O. Akpa, A. O. Ayeni and S.O Adedeji (eds) Access, Equity and Quality in Higher Education, National Association for Educational Administration and planning. (NEAP) Publication.

Nwokike, F.O. (2015). Influence of incessant strikes on acquisition of employable skills in word processing as perceived by business education teachers and students in Universities in Enugu State. Nigerian Journal of Business Education, 2(2), 296-304.

Okorie, J.A. (2013). Quality assurance and the challenge of mandate delivery in the Nigerian University System. A special Address presented at the Lagos State University, $18^{\text {th }}$ Convocation Lecture, Lagos State, Nigeria.

Co, M. J., \& Mitchell, B. (2006). Entrepreneurship education in South Africa: A national survey. Education and Training, 48(5), 357-358.

Byun, C., Sung, C. S., Park, J. Y. \& Choi, D. S. (2018). A study on the effectiveness of entrepreneurship education programmes in higher education institutions: A case study of Korean Graduate Programs. Journal of Open Innovation: Technology, Market and Complexity, 4(26), 1-14.

Harbau, M. I. (2014). Needs for curriculum review and capacity building for successful management of entrepreneurship education in Federal College of Education, Zaria. Journal of Vocational Studies, 8(1), 107-119.

Mwatsika, C. \& Sankhulani, E.(2016). Effect of entrepreneurship education on students' orientation towards entrepreneurship at the Malawi Polytechnic. International Journal of Business and Economic Research, 5(6), 235-245.

Onagite, O. G. \& Aina, M. A. (2017). School based practices for entrepreneurship skill acquisition in secondary schools in Delta State of Nigeria. International Journal of Vocational Education and Training Research, 3(5), 40-50. 